\title{
RELATIONSHIPS WITH CITIZENS IN PUBLIC MANAGEMENT: A STUDY AT THE LARGEST SPANISH TOWN HALLS ${ }^{1}$
}

\author{
Reyes González. SIRHO Group. Business Organisation Department. University \\ of Alicante
}

Juan Llopis. SIRHO Group. Business Organisation Department. University of Alicante

José Gascó. SIRHO Group. Business Organisation Department. University of Alicante

\begin{abstract}
:
The present paper provides an analysis of the relationships between citizens' participation and satisfaction in the context of Spanish local administrations; attention will equally be paid to the links between organisational size and participation and satisfaction levels. With these aims in mind, we examine the results of a survey questionnaire that was answered by 388 Human Resources (HR) managers from the largest Spanish Town Halls.

The foundation for this paper stems from the change of paradigm which has taken place within the framework of public management towards New Public Management during the last few years. Amongst other things, this paradigm implies a new type of relationship between public administrations and citizens where the passive role of the latter as addressees of services in a situation of subordination is going to be replaced by a more active role performed in a context of greater equality. In this respect, a claim is made both to increase the degree of participation of citizens in public decisions and to ensure the delivery of public services which meet citizens' needs.
\end{abstract}

\section{Keywords:}

Participation, satisfaction, public management, survey

\footnotetext{
1 This article was written thanks to the funding provided by the Office of the Vice Chancellor for Research, Development and Innovation of the University of Alicante (GRE- 09-08) and the Regional Department of Education of the Generalitat Valenciana [Valencian Regional Government] (GV72011/029).
} 


\section{RELATIONSHIPS WITH CITIZENS IN PUBLIC MANAGEMENT: A STUDY AT THE LARGEST SPANISH TOWN HALLS}

\section{INTRODUCTION}

In recent years, Public Sector management has come to be placed within a form of government known as New Public Management (NPM). Although NPM fosters values and goals of an economic nature, it is still a multifaceted concept which contains different elements. Its main component is the search for a type of professional management which makes possible an active, visible and discretionary control over public organisations exerted by persons who are free to perform this direction task. It additionally entails the establishment of explicit result standards, a stronger emphasis on result control, increased competitiveness, unit disaggregation, deregulation, orientation towards customer service and the utilisation of management techniques from the private sector (Christensen \& Laegreid, 2002).

Another of the claims made by NPM has to do with the need for collaboration between the government and public administrations on one side and citizens on the other. Collaboration means participation, negotiation, cooperation, freedom and an unlimited information flow, innovation, agreements based on commitments and mutual understanding; in short, it implies a more equitable distribution and redistribution of power and resources. Many of these values are totally opposed to the hierarchy, specialisation and impersonality assigned to modern bureaucracies (Vigoda, 2002). The administration style applied to public management in Continental Europe is based on administrative law. These countries, among which is Spain, try to fit the reforms of public administration and NPM into their bureaucratic models seeking to improve not only the participation of citizens and employees but also service quality, moving towards a greater focus on the citizen while overlapping it with their traditional administration systems (Torres, Pina \& Acerete, 2005).

The orientation towards the citizen as a 'customer' is another of the aspects proposed by NPM. This orientation forces public administrations to adopt a number of specific stances; on the one hand, public services must be delivered with a view to satisfy customers' needs rather than depending on the predisposition of organisations; and on 
the other hand, public authorities must seek the highest possible involvement of people when it comes to model the choices which are available to them ( $\mathrm{Ra} \&$ Joo, 2005).

The present study has as its aim to analyse the relationships that the administration maintains with citizens, examining the interactions between citizens' participation and satisfaction in the specific context of local administrations. According to our starting hypothesis, a greater involvement of citizens will lead to better services and, consequently, to a greater satisfaction with those services. On the other hand, the determining factors for both variables -satisfaction and participation-include individual ones associated with the citizens themselves but also other organisational factors related to local administrations. In our case, the emphasis will be placed on analysing the relationship between organisational size and citizen satisfaction and participation. The whole study is going to be illustrated with the results of a survey carried out among the largest Spanish town halls. The rest of the paper is structured as follows: a thorough review of the literature devoted to citizens' participation and satisfaction in public management will give way to the presentation of the methodology applied in our field study along with the most significant results and conclusions derived from it.

\section{RELATIONSHIPS WITH CITIZENS: A LITERATURE REVIEW}

\subsection{Participation}

One of the main goals of the 'old public administration' was to preserve and protect the rights of individuals; that is why the State had to be an efficient and effective provider of goods and services and information within a relationship regulated by the State. This was a unidirectional relationship: from the administration towards the citizens. Nevertheless, NPM starts with the assumption of democratic motivations to become involved in the public sphere. This structure conceives public interest as the result of a dialogue; it regards people as citizens and not as customers or consumers, and the first role of the public administration is to serve, to facilitate the participation and to collaborate with citizens rather than merely implementing schemes preconceived for customers (Brainard \& McNutt, 2010). The door is consequently opened to a bidirectional relationship between public administration and citizens.

The role of 'customers' or 'consumers' assigned to citizens denotes a passive orientation among the latter with regard to the administration, which is the active part trying to satisfy the needs of those 'customers' (Aberbach \& Christensen, 2005). This dependency pattern may create serious hindrances in the reforms of public bodies and 
interrupt the emergence of better services. The paradox between serving customers and collaborating with citizens' needs to be resolved finding a way to create public organisations with better results (Vigoda, 2002). That is why, in recent years, public administrations have considerably changed their ways of working and their relationships with citizens, which could previously be defined as formal and authoritarian (Brainard \& McNutt, 2010), trying to collaborate with them as well as with other agencies and making an effort to involve citizens in the configuration of the services that they wish to receive (Newman, Barnes, Sullivan \& Knops, 2004). Nevertheless, we are witnessing how participation is encouraged with strategies such as e-government (Cotteril \& King, 2007), which imply a stronger connection between citizens and the administration but simultaneously part of the citizenship don't want to take part in public life whihc is reflected, for instance, in low voting rates in election processes or low political party membership levels (Lowndes, Pratchett \& Stoker, 2006).

However, what do we understand by 'participation'? This appears as an imprecise concept, since there is a need not only to define exactly which community is going to participate but also to describe the activity in which that participation takes place. Does participation mean the provision of information to citizens, the consultation or an association between the community and a government body, or does it mean control by the community over the decisions which are usually adopted by the representative institution? (Kluvers \& Pillay, 2009). Participation can be defined as taking part in a process of formulation, development and implementation of public policies. Such a definition includes not only voting but also contacting officials or politicians, attending demonstrations and being formally or informally involved in local issues (Lowndes, Pratchett \& Stoker, 2006). For some people, participation merely consists in an upward or downward information exchange, or any consultation on the part of citizens; others argue that participation cannot be conceived without agreement and dialogue, or the comanagement or co-production of services; and finally there are those who see participation initiatives simply as an image policy meant to legitimise political action and for whom true participation can only exist when citizens share a delegated power to adopt the collective decisions that affect them (Colino \& Del Pino, 2003). The characteristics of participation include: an assessment of citizens' involvement in decisions which otherwise could exclusively be a prerogative of the government; a commitment to know the points of view and perspectives of those affected by the 
decision; some authority transfer from the government to citizens; a transparent process ensuring that citizens are informed about political processes (Kluvers \& Pillay, 2009). These definitions serve as the basis for our treatment of citizen participation in this study through two approaches: the participation of citizens through mixed committees formed by town halls and residents associations; and the communication of public policies seeking citizen participation.

Participation is important because it improves the decisions of local administrations thanks to the fact that they have at their disposal information from the citizens' point of view; therefore, participation can help to improve the services delivered (Lowndes, Pratchett \& Stoker, 2001a). That participation will only be achieved if the elected representatives and public sector managers desire it, allow it and encourage it; participation cannot occur unless public service managers consider it desirable and are prepared to promote it (Kluvers \& Pillay, 2009) generating a context within which participation appears as a positive behaviour on the part of citizens. Furthermore, the public authorities must provide people with incentives for mobilisation or participation. In other words, not only there needs to be a feeling among citizens that they can do something to improve politics; they must also feel that their voice is heard, that there is a response from the administrations (Lowndes, Pratchett \& Stoker, 2006).

Nevertheless, it is worth bearing in mind that more participation does not mean the same as more democracy, since participation initiatives can strengthen the dominating social exclusion and disadvantage patterns (Brainard \& McNutt, 2010). A whole set of barriers and hindrances to participation may additionally exist; for example, the reason why many citizens do not participate is simply ignorance; not enough information is supplied by the administrations about the ways in which citizens can take part in public decision making. It may awake unreal or unfeasible expectations among citizens or lead them to believe that their interests come into conflict with general policies. Another associated problem is slowness, that is, the citizen's consultation or participation is likely to slow down the decision-making process, which is already slow in highly bureaucratic public systems. Other problems have to do with the increase of costs in the decision-making process, as implementing the participation or consultation process has a price, and this can become an additional burden for the local government members who are already not too enthusiastic about participation. It must also be remembered that the authorities should seek the participation of specific groups which are not 
representative of the vast majority. Many citizens think that "participation is not for me," which reveals social exclusion problems; these are citizens who exclude themselves from citizen participation, showing their own prejudice about their lack of training and the little interest which can actually be assigned to their opinions. It is also worth highlighting that participation can undermine the authority and legitimacy of democratically elected politicians (Lowndes, Pratchett \& Stoker, 2001a and 2001b; Colino \& Del Pino, 2003; King \& Cotterill, 2007).

The explanations or reasons leading to higher participation depend on individual and contextual factors (Höpner, Frick \& Buchecker, 2008). The individual ones would include the social, demographic and economic features of the individuals who are entitled to participate, such as their age, gender, income level, socio-economic status and cultural or educational level (Agarwal \& Gupta, 2005). However, the characteristics of the administrations themselves can influence the degree of participation as well; for instance, local administrations with a larger population are expected to be in the vanguard of participation (Christensen \& Laegreid, 2002). This leads us to think that the size of organisations is likely to become a determining factor for citizen participation levels.

\subsection{Satisfaction and Image}

In the past, many public organisations paid little attention to service quality or lacked sensitivity towards customers - citizens in this case; but this is changing with the arrival of the movement known as NPM (Saxena, 2005). NPM means that the public sector needs to be more efficient, seeking positive results in its management. Until recently, the public administration only used 'hard' indicators (such as resources or outputs) to control those results. However, the difficulty in counting them has stimulated the use of 'soft' indicators such as satisfaction degree (Bouckaert \& Van de Walle, 2003).

The attention paid to satisfaction indicators and, in general, to subjective indicators, is not new. An increase of surveys with a social orientation and, on the whole, of surveys specifically focused on satisfaction degree, especially in relation to local services, took place during the late 1970s and early 1980s. Greater interest has been raised since the early 1990 s by the use of social measurements due to the research levels from economics faculties and to the growing interest in the customer-oriented approach within the public sector, which in turn encouraged the study of satisfaction surveys (Bouckaert \& Van de Walle, 2003, Morgeson \& Petrescu, 2011). 
Some studies to determine citizen satisfaction levels in relation to public services are based on demographic variables, such as citizens' race, age and sex or their income and dwelling ownership level (Dehoog, Lowery \& Lyons, 1990). However, another way to measure this level of satisfaction is according to political effectiveness. The feeling of integration into the community can equally affect the assessments about local service quality levels (DeHoog, Lowery \& Lyons, 1990).

On the other hand, a direct causal relationship is presupposed between the quality of a specific service and user satisfaction; that is, if quality increases, satisfaction is also expected to increase (Bouckaert \& Van de Walle, 2003); cities with more and higherquality services will be more favourably perceived by their inhabitants than those with fewer and lower-quality services (DeHoog, Lowery \& Lyons, 1990). Nevertheless, this relationship between quality and satisfaction is not always direct, due not only to the discrepancies between producers and consumers regarding their vision of quality and to changes in the expectations about services but also to their different characteristics (Bouckaert \& Van de Walle, 2003).

Because it is not easy to measure satisfaction directly, we will try to determine it through the image or perception that citizens have about the public sector, as has already been done in other studies (Morgeson \& Petrescu, 2011). Authors such as Vigoda (2002) consider that the opinion of service addressees, the citizens, is a good indicator of public policy results. Four items are used to know that opinion: a) Attention to the public compared to other town halls; b) Image in specific areas (e.g. culture, education, sports or social services), c) An image of commitment and staff training as opposed to an image of bureaucrats; and d) An image of efficiency and innovation.

a) Attention to the public compared to other town halls. NPM lays more emphasis on consumer sovereignty, encourages public organisations to place consumers first and to orient services towards their preferences and demands (Aberbach \& Christensen, 2005). Attention to citizens' needs is the main raison d'être for the public sector, since its material or financial existence depends on citizens as 'taxpayers,' which is why covering their needs and expectations becomes an obligation (Haque, 1999). The use of technologies in recent years has permitted a more direct and quick attention to citizens, with more accessible and thorough information and better communication channels that can bridge the communication and information gap between citizens and the public sector (Welch, Hinnant \& Moon, 2004). Moreover, it is worth highlighting the comparison that a public body can receive with respect to other similar institutions, as 
this benchmarking action will most probably favour an orientation towards best practice policies in public management (Morgeson \& Petrescu, 2011)

b) Image in specific areas (e.g. culture, sports or social services). It is necessary to be more specific regarding certain areas in order to describe the existing image or perception about them; if we take public services as an aggregate (and abstract) whole, it becomes difficult for the public to make an assessment of them (Bouckaert \& Van de Walle, 2003).

c) An image of commitment and staff training as opposed to an image of bureaucrats. The typical -and pejorative- image of a public administration is that of a complex, highly formalised and delimited organisational structure where only ambiguous goals have been set (Christensen \& Laegreid, 2002). In parallel, the typical -and pejorativeimage of a public service employee is that of a bureaucrat focused on doing his job without any commitment to ongoing improvement, to agility in attention to the public or to recycling and training level improvement; but all of this has been changing rapidly in recent years. Despite the relative low salaries in the public sector, there are many public employees who are committed to their job, not due to essentially monetary incentives (more common in private enterprises) but to others more intrinsic to their role as the desire to serve public interest, the feeling of patriotism, the sense of participation in the most important public policies and the need to do something good for the public in general (Haque, 1999).

d) An image of efficiency and innovation. Efficiency and innovation are two of the key aspects in NPM. The public administration must have positive results; it cannot waste, it must be efficient. Citizens should be more satisfied with more efficient public services (Welch, Hinnant \& Moon, 2004). However, efficiency is repeatedly sought taking as a reference the comparison with the private sector (Teicher, Hughes \& Dow, 2002) and it should be remembered that public management cannot be totally comparable to private enterprise management. Similarly, an excessive emphasis on efficiency is likely to compromise issues of a public nature such as equality, representation, public interest, human dignity or justice (Haque, 2001).

On the other hand, innovation has been promoted as a tool for the improvement of public services by governments from all over the world. Financial pressures and bureaucratic controls, along with the demands for better services, make innovation difficult but also necessary as the only useful way to approach and give a response to citizens' requests (Robertson \& Ball, 2002). 


\section{METHODOLOGY FOR THE EMPIRICAL STUDY}

The information in the empirical study is obtained from a questionnaire sent to the town halls of the largest Spanish cities, taking into account the number of inhabitants as a town hall size index. The database called La Web Municipal ${ }^{2}$ [The Municipal Website] was used to achieve this aim. Although looking for multiple information sources at each town hall might have been interesting in order to provide a more varied perspective in the results, we decided to administer the questionnaire only to the Human Resources (HR) Manager because the utilisation of a single informant could allow us to obtain better response ratios as well as a homogeneous comparison. Furthermore, unlike what happens in other countries, the figure of the general manager does not exist in Spanish town halls; that is why the figure of the HR manager is relevant to answer our questions. The questionnaire was prepared on the basis of the literature dedicated to strategic management in town halls and was reviewed by three experts in local administration management. It was later uploaded to a web page and a postal letter was sent to the different town halls for the attention of the HR manager in which we kindly requested them to complete the questionnaire the link for which appeared on the letter. A telephone follow-up was carried out next, thanks to which we had access to each HR manager's electronic mail and/or phone number, after which a second call was made by electronic mail. A final telephone call was made in order to increase the response rate. We obtained 388 responses out of 1,000 town halls interviewed; that represents a $38.8 \%$ response rate (sampling error, 3.8\%). Table 1 shows the study technical specifications. It is worth highlighting that the number of responses is higher than or similar to those obtained in other research studies carried out in local administrations. The town halls which answered the questionnaire are representative of the total population in terms of size (measured by number of inhabitants) and regarding territorial distribution, since every autonomous region is represented in the sample (see Table 1).

INSERT TABLE 1

Table 2 shows the measures corresponding to the variables used in the study along with their reliability level.

INSERT TABLE 2

\footnotetext{
${ }^{2}$ http://www.lawebmunicipal.com
} 


\section{RESULTS}

\subsection{Characteristics of Town Halls and of the Interviewees}

The town halls which answered the questionnaire have a large size, as their average number of inhabitants exceeds 40,000 and also that they are organisations with an average annual budget of more than 93 million euros and a staff volume of nearly 400 workers on average.

As for the interviewees (Figure 1), because the survey had as its addressees HR managers at local governments, it can be seen that a high response percentage comes from these jobs or positions (42\%), but we also find interviewees who identify themselves as HR technicians $(24 \%)$ or HR administrative workers $(11 \%)$. The reason for this undoubtedly lies in the fact that these are the smallest town halls where the tasks associated with HR are performed by individuals who, despite their position and responsibilities, are not seen as belonging to the 'head' category. Moreover, the survey respondents were politicians (mayor, deputy mayor, town hall secretary) in $8 \%$ of the cases.

\section{INSERT FIGURE 1}

It can be checked how the interviewees were mostly men, although without an excessive imbalance ( $56 \%$ of men as opposed to $44 \%$ of women) and how their age ranges are largely situated between 40 and 49 years of age. On the other hand, a majority of interviewees belong to group A (78\%) -this group is formed by the staff who need a university degree for their job. Far fewer workers are located in group C, the administrative staff for whom university studies are not a requirement. Although $40 \%$ of the interviewees do not have a high seniority, as they have developed their professional activity during a period of up to 5 years, the average seniority at the post is 10 years. In our opinion, all these features about our interviewees' profile allow us to state that they fulfil the necessary requirements in terms of training, seniority, hierarchy and working position that make them apt to answer all the items included in our survey questionnaire.

\subsection{Relationships with citizens}

\subsubsection{Citizen participation}

The degree of citizen participation at the Town Hall (Table 3) is not very high judging by the previous information provided to citizens about the municipal policies which are 
going to be implemented and by the scarce involvement of citizens in mixed committees (formed by town halls and residents associations).

\section{INSERT TABLE 3}

The largest municipalities -those with more inhabitants, greater staff volumes and higher budgets- are the ones where citizen participation plays a more relevant role in the decisions adopted by the town halls themselves, above all through the creation of mixed committees with members coming from town halls and residents associations (Table 3). In the case of municipalities with higher budgets, it can additionally be verified that town halls take a greater interest in the previous communication of the policies that are going to be developed so that citizens can express their opinion about them.

\subsubsection{Satisfaction, Town Hall Image}

As we said before, the satisfaction of the citizens with the town halls will be measure through the image of these organisms. It is worth highlighting (Table 4) that this image is not excessively positive, but not totally negative either. Especially outstanding aspects on the favourable side are its attention to the public and its good image in the areas offered by town halls, such as culture, education, sports or social services. However, citizens do not have a particularly high opinion of town hall staff as being committed and well-trained people and, even less, of their efficiency or innovation capacity.

\section{INSERT TABLE 4}

A means difference analysis (Table 4) referred to town hall size (municipality inhabitants, town hall staff numbers and town hall budget) reveals that the smallest town halls (in municipalities with fewer inhabitants and smaller staff volumes) are better valued in terms of attention to the public and in the perception of their workers as committed people and not simply bureaucrats. Small size may improve the proximity of municipal staff to their customers (their fellow citizens). However, the town halls with the highest budgets are seen as more innovative and efficient and, on the whole, their image is more highly valued in the services that they offer (culture, education, etc.). Perhaps it is their higher budget that precisely helps them both to deliver better services and to be more innovative and efficient.

\subsubsection{Participation and Satisfaction Level}


A study of the relationship between citizens' degree of participation in local decisions and their general level of satisfaction with those administrations comes next. With this aim in mind, and on the basis of the four items which identify it, we designed a variable which could measure that level of satisfaction from the said four identifying items. The name given to this variable was 'satisfaction degree'3. This variable discriminates whether citizens in one municipality are more or less satisfied than the average citizen. Its calculation results from adding the scores (from 1 to 7 ) given to the items in the question about satisfaction with town halls, as a result of which a variable known as 'satisfaction sum' is built. We calculated the mean and median for that variable (17.077 and 18 , respectively). Thus, the variable 'satisfaction degree' arises from giving a 0 value to town halls when their satisfaction sum is below 18 and a 1 value otherwise. This permits to establish a rather balanced central cut-off measure (with 188 town halls where satisfaction is below the average and 200 town halls with above-the-average satisfaction levels.

INSERT TABLE 5

The relation between satisfaction degree and citizen participation was calculated using Table 5 (correlations and means test).

It can be observed that the town halls where citizens are more satisfied are also the ones providing a higher level of citizen participation, both through the previous communication of governmental policies and through mixed committees.

\section{CONCLUSIONS}

Our study reflects the moderate or reduced involvement of citizens in public decisions in the case of Spanish town halls. Nevertheless, among these town halls, larger-sized ones offer more chances for participation than smaller-sized ones, especially through mixed committees formed in Town Halls and residents associations. Furthermore, the town halls with higher budgets take more interest in the previous communication offered to citizens about the policies that are being developed so that citizens can express their opinion about them. Our conclusions do not contradict previous results

\begin{tabular}{lcr}
\hline 3 & & \\
\hline Satisfaction degree & No. & \multicolumn{1}{c}{$\%$} \\
\hline Below the mean & 188 & 48.5 \\
Above the mean & 200 & 51.5 \\
Total & 388 & 100.0 \\
\hline
\end{tabular}


according to which there are few activist citizens who are deeply involved in public life and have citizen initiatives for the community. Even the most optimistic calculations suggest that their proportion is less than $10 \%$ of the population (Vigoda, 2002). This is probably due to the fact that people like more the idea than the reality of participating (Lowndes, Pratchett \& Stoker, 2001b).

The low participation levels may be due to the fact that participation is not sufficiently promoted by local administrations, in which case public administrations should make an effort to encourage and support participation levels, since another of the conclusions drawn from our study refers to the existence of a direct, positive relationship between participation and good image, or citizens' satisfaction with their local administrations; in other words, if the citizens become more involved, they are more satisfied or the image of public management improves.

As for the satisfaction or the image that citizens have about Spanish local administrations, a special mention on the favourable side must be made of their attention to the public and their good image in specific services such as culture, education, sports or social services. Town halls are not too highly valued for the perception of their staff as committed and well-trained people or for that staff's efficiency or innovation capacity. Nevertheless, significant differences can be found between the size of town halls and citizens' satisfaction with them; that is, town halls with fewer workers in cities with a smaller population stand out for their attention to the public and because they have a staff of committed people and not merely bureaucrats. This may mean that smaller size facilitates relationships and proximity between the town hall staff and their customers, who are their fellow citizens. However, town halls with more economic resources, with a higher budget, are seen as the most innovative and efficient ones and their image is more highly valued in the services that they offer. Their greater resources probably help them both to deliver better services and to be more efficient and innovative.

In short, as far as relationships with citizens are concerned, both in terms of satisfaction or image and regarding participation, a high degree of relevance must be assigned to organisational characteristics -town hall size in this case- and not only to the possible features of citizens, which have not been analysed in this study.

With regard to the limitations faced in this paper, they mainly refer to the survey respondent, as we are obtaining results from the opinions of HR managers about citizens' degree of participation in local administrations and about the image that those 
citizens have about town halls and, consequently, about their satisfaction level. The same limitation was present in the study of Kluvers \& Pillay (2009), which is why, exactly the same as these authors did, we must clarify that the study does not refer so much to participation and satisfaction levels as to the interviewees' perception of such levels.

Moreover, there may be limits to interpretation if concepts based on competence or perceptions are questioned, since the answer is being given from the perspective of a single person, and not from that of the whole organisation. However, the response rate is high and these inconveniences would be compensated if the respondents are senior staff -as in our case (Lowndes, Pratchett \& Stoker, 2001a).

Of course, it would be very interesting for this analysis to incorporate the perspective and opinion of the citizens themselves, a limitation which has been equally recognised in other similar research works about public management (Lowndes, Pratchett \& Stoker, 2001b).

\section{REFERENCES}

Aberbach, J. \& Christensen, T. (2005). "Citizens and Consumers". Public Management Review, Vol. 7, No. 2, pp. 225-246.

Agrawal, A. \& Gupta, K. (2005). "Decentralization and Participation: The Governance of Common Pool Resources in Nepal's Terai”. World Development, Vol. 33, No. 7, pp. 1101-1114.

Bouckaert, G. \& Van de Walle, S. (2003). "Comparing measures of citizen trust and user satisfaction as indicators of 'good governance': difficulties in linking trust and satisfaction indicators". International Review of Administrative Sciences. Vol. 69. No. 3, pp. 329-343.

Brainard, L.A. \& McNutt, J.G. (2010). "Virtual government-citizen relations: Informational, transactional or collaborative?", Administration \& Society, Vo. 42. No. 7, pp. 836-858.

Christensen, T. \& Lægreid, P. (2002). "New Public Management: Puzzles of Democracy and the Influence of Citizens". Journal of Political Philosophy. Vol. 10, No. 3, pp. 267-295.

Colino, C. \& Del Pino, E. (2003). "Un fantasma recorre Europa: Renovación democrática mediante iniciativas de Promoción Participativa en los Gobiernos Locales". Segundas Jornadas de Sociología Política. UNED. Madrid 11-12 Dic.

Cotterill, S. \& King, S. (2007). "Public Sector Partnerships to Deliver Local EGovernment: a Social Network Study". Electronic Government, Vol. 4656, pp. 240251. 
DeHoog, R.H.; Lowery, D. \& Lyons, W.E. (1990). “Citizen Satisfaction with Local Governance: A Test of Individual, Jurisdictional, and City-Specific Explanations". The Journal of Politics Vol. 52, pp. 807-837.

Haque, M.S, (1999). "Relationship between citizenship and Public Administration: a reconfiguration". International Review of Administrative Sciences. Vol. 65. No. 3, pp. 309-325.

Haque, M.S. (2001). "The Diminishing Publicness of Public Service under the Current Mode of Governance”. Public Administration Review, Vol. 61, No. 1, pp. 65-82.

Höppner, C.; Frick, J. \& Buchecker, M. (2008). “What Drives People's Willingness to Discuss Local Landscape Development?”. Landscape Research, Vol. 33, No. 5, pp. 605622.

King, S. \& Cotterill, S. (2007). "Transformational Government? The Role of Information Technology in Delivering Citizen-Centric Local Public Services". Local Government Studies. Vol. 33, No. 3, pp. 333-354.

Kluvers, R. \& Pillay, S. (2009). "Participation in the Budgetary Process in Local Government”. Australian Journal of Public Administration. Vol. 68, No. 2, pp. 220-230.

Lowndes, V.; Pratchett, L. \& Stoker, G. (2001a). "Trends in Public Participation: Part 1 - Local Government Perspectives”. Public Administration, Vol. 79, No. 1, pp. 205-222.

Lowndes, V.; Pratchett, L. \& Stoker, G. (2001b). "Trends in Public Participation: Part 2 - Citizens' Perspectives". Public Administration, Vol. 79, N. 2, pp. 445-455.

Lowndes, V.; Pratchett, L. \& Stoker, G. (2006). "Local Political Participation: the Impact of Rules-In-Use”. Public Administration. Vol. 84, No. 3, pp. 539-561.

Morgeson, F. V. \& Petrescu, C. (2011). "Do They All Perform Alike? An Examination of Perceived Performance, Citizen Satisfaction and Trust with US Federal Agencies". International Review of Administrative Sciences. Vol. 77, No. 3, pp. 451-479.

Newman, J.; Barnes, M.; Sullivan, H. \& Knops, A. (2004). "Public articipation and Collaborative Governance”. Journal of Social Policy, Vol. 33, No. 2, pp. 203-223.

Ra, H-M. \& Joo, J. (2005). "Evaluating customer-centered reforms in Korean local governments: possibilities and limitations of reform measures for civil application". International Review of Administrative Sciences, Vol. 71 No. 3, pp. 425-444.

Robertson, R. \& Ball, R. (2002). "Innovation and Improvement in the Delivery of Public Services: The Use of Quality Management within Local Government in Canada". Public Organisation Review: a Global Journal, Vol. 2, No. 4, pp. 387-405.

Saxena, K.B.C. (2005). "Towards excellence in e-governance". International Journal of Public Sector Management. Vol. 18. No. 6. 2005.

Teicher, J.; Hughes, O. \& Dow, N. (2002). "E-government: a new route to public sector quality". Vol. 12. No. 6, pp. 384-393.

Torres, L. Pina, V. \& Acerete, B. (2005). "E-government Developments on Delivering Public Services among EU cities". Government Information Quarterly. Vol. 22, No. ?? pp. 217-238.

Vigoda, E. (2002). "From responsiveness to collaboration: Governance, citizens, and the next generation of public administration". Public Administration Review, Vol. 62, No. 5, pp. 527-540. 
Welch, E.W.; Hinnant, Ch.C. \& Moon, M.J. (2004). "Linking Citizen Satisfaction with E-Government and Trust in Government”. Vol. 15, No. 3, pp. 371-391. 
Table 1: Study Technical Specifications

\begin{tabular}{ll}
\hline Scope & Spain \\
Population & 1,000 largest Town Halls (by population) \\
Sampling size & $388(38.8 \%)$ \\
Sampling error & $3.8 \%$ \\
Survey date & July 2009-March 2010 \\
\hline
\end{tabular}

Table 2: Measurements of variables and Reliability

\begin{tabular}{|l|l|l|c|}
\hline \multicolumn{1}{|c|}{ Construct } & \multicolumn{1}{|c|}{ Source } & \multicolumn{1}{c|}{ Measuring Scale } & $\begin{array}{c}\text { Reliability } \\
(\text { Cronbach's } \alpha)\end{array}$ \\
\hline $\begin{array}{l}\text { Relationship with citizens: } \\
\text { Participation }\end{array}$ & $\begin{array}{l}\text { Lowndes, Pratchett \& } \\
\text { Stoker (2006) and own } \\
\text { materials }\end{array}$ & 2 items, 1-7 Likert scale & 0.767 \\
\hline $\begin{array}{l}\text { Relationships with citizens: } \\
\text { Image, satisfaction }\end{array}$ & $\begin{array}{l}\text { Lowndes, Pratchett \& } \\
\text { Stoker (2001a) and own } \\
\text { materials }\end{array}$ & 4 items, 1-7 Likert scale & 0.894 \\
\hline $\begin{array}{l}\text { Relationship with Citizens: } \\
\text { Means }\end{array}$ & $\begin{array}{l}\text { Lowndes, Pratchett \& } \\
\text { Stoker (2001b) and own } \\
\text { materials }\end{array}$ & 7 items, 1-7 Likert scale & 0.740 \\
\hline
\end{tabular}

Table 3: Means difference test: citizen participation according to size (inhabitants, staff, budget)

\begin{tabular}{|c|c|c|c|c|c|c|}
\hline \multicolumn{9}{|c|}{ Citizen participation } & \multicolumn{2}{c|}{ Mean (Standard Deviation) } \\
\hline \multicolumn{2}{|c|}{ Participation with mixed committees (Town Hall/associations) } & \multicolumn{3}{|c|}{$3.4639(2.10849)$} \\
\hline Previous communication of policies to citizens & $\begin{array}{c}\text { Mixed } \\
\text { committees }\end{array}$ & F & Sign. & $\begin{array}{c}\text { T (Student) } \\
\text { or U Mann- } \\
\text { Whitney }\end{array}$ & Sign. \\
\hline No. of Inhabitants & $\begin{array}{c}\text { Above average } \\
\text { Below average }\end{array}$ & $\begin{array}{l}4.0309 \\
2.8969\end{array}$ & 3.375 & 0.067 & 12810 & 0.000 \\
\hline No of workers & $\begin{array}{c}\text { Above average } \\
\text { Below average }\end{array}$ & $\begin{array}{l}3.9213 \\
3.1222\end{array}$ & 12.015 & 0.001 & 11238 & 0.000 \\
\hline Budget & $\begin{array}{c}\text { Above average } \\
\text { Below average }\end{array}$ & $\begin{array}{l}3.9375 \\
2.2500\end{array}$ & 5.960 & 0.016 & 1160 & 0.000 \\
\hline & $\begin{array}{c}\text { Previous } \\
\text { communication }\end{array}$ & & & & \\
\hline Budget & $\begin{array}{c}3.6563 \\
\text { Above average } \\
\text { Below average }\end{array}$ & 2.7500 & 3.007 & 0.085 & 2.787 & 0.006 \\
\hline
\end{tabular}


Table 4: Means difference test: Image (satisfaction) according to size (inhabitants, workers, budget)

\begin{tabular}{|c|c|c|c|c|c|c|}
\hline \multicolumn{4}{|c|}{ Citizens' Satisfaction (Town Hall Image) } & \multicolumn{3}{|c|}{ Mean (Standard Deviation) } \\
\hline \multicolumn{4}{|c|}{ Attention to the Public } & \multicolumn{3}{|c|}{$5.0155(1.51300)$} \\
\hline \multicolumn{4}{|l|}{ Good Image } & \multicolumn{3}{|c|}{$4.6340(1.65658)$} \\
\hline \multicolumn{4}{|c|}{ Committed People } & \multicolumn{3}{|c|}{$3.8454(1.68496)$} \\
\hline \multicolumn{4}{|c|}{ Effective and Innovative } & \multicolumn{3}{|c|}{$3.5825(1.62535)$} \\
\hline Size & & $\begin{array}{l}\text { Attention to } \\
\text { the Public }\end{array}$ & $\mathrm{F}$ & Sign. & $\begin{array}{l}\text { T (Student) or U } \\
\text { Mann-Whitney }\end{array}$ & Sign. \\
\hline $\begin{array}{c}\text { No. of } \\
\text { Inhabitants }\end{array}$ & $\begin{array}{l}\text { Above average } \\
\text { Below average }\end{array}$ & $\begin{array}{l}4.8144 \\
5.2165\end{array}$ & 0.130 & 0.719 & -2.637 & 0.009 \\
\hline No. of workers & $\begin{array}{l}\text { Above average } \\
\text { Below average }\end{array}$ & $\begin{array}{l}4.8539 \\
5.1778\end{array}$ & 0.195 & 0.659 & -1.999 & 0.046 \\
\hline & & $\begin{array}{l}\text { Committed } \\
\text { People }\end{array}$ & & & & \\
\hline $\begin{array}{c}\text { No. of } \\
\text { Inhabitants }\end{array}$ & $\begin{array}{l}\text { Above average } \\
\text { Below average }\end{array}$ & $\begin{array}{l}3.5876 \\
4.1031 \\
\end{array}$ & 0.016 & 0.900 & -3.045 & 0.002 \\
\hline No. of workers & $\begin{array}{l}\text { Above average } \\
\text { Below average }\end{array}$ & $\begin{array}{l}3.5730 \\
4.0556 \\
\end{array}$ & 0.158 & 0.691 & -2.695 & 0.007 \\
\hline & & $\begin{array}{l}\text { Efficient, } \\
\text { Innovative }\end{array}$ & & & & \\
\hline Budget & $\begin{array}{l}\text { Above average } \\
\text { Below average }\end{array}$ & $\begin{array}{l}4.1250 \\
3.1563\end{array}$ & 6.903 & 0.010 & 1398 & 0.002 \\
\hline & & Good image & & & & \\
\hline Budget & $\begin{array}{l}\text { Above average } \\
\text { Below average }\end{array}$ & $\begin{array}{l}5.0938 \\
4.5000\end{array}$ & 7.670 & 0.006 & 1.632 & 0.042 \\
\hline
\end{tabular}

Table 5: Correlations and means difference test (Participation, Satisfaction level)

\begin{tabular}{|c|c|c|c|c|c|c|c|c|}
\hline & & & & & Levene & & & \\
\hline Participation & $\begin{array}{c}\text { Pearson's } \\
\text { R }\end{array}$ & Sign. & $\begin{array}{l}\text { Satisfaction } \\
\text { Level }\end{array}$ & Mean & $\mathrm{F}$ & Sign. & $\mathrm{T}$ (Student) & Sign. \\
\hline $\begin{array}{c}\text { Mixed } \\
\text { Committees }\end{array}$ & 0.238 & 0.000 & $\begin{array}{l}\text { Above average } \\
\text { Below average }\end{array}$ & $\begin{array}{l}3.9500 \\
2.9468\end{array}$ & 0.578 & 0.448 & -4.816 & 0.000 \\
\hline $\begin{array}{c}\text { Previous } \\
\text { Communication }\end{array}$ & 0.346 & 0.000 & $\begin{array}{l}\text { Above average } \\
\text { Below average }\end{array}$ & $\begin{array}{l}4.0800 \\
2.7340\end{array}$ & 2.373 & 0.124 & -7.244 & 0.000 \\
\hline
\end{tabular}

Figure 1: Interviewees' profile
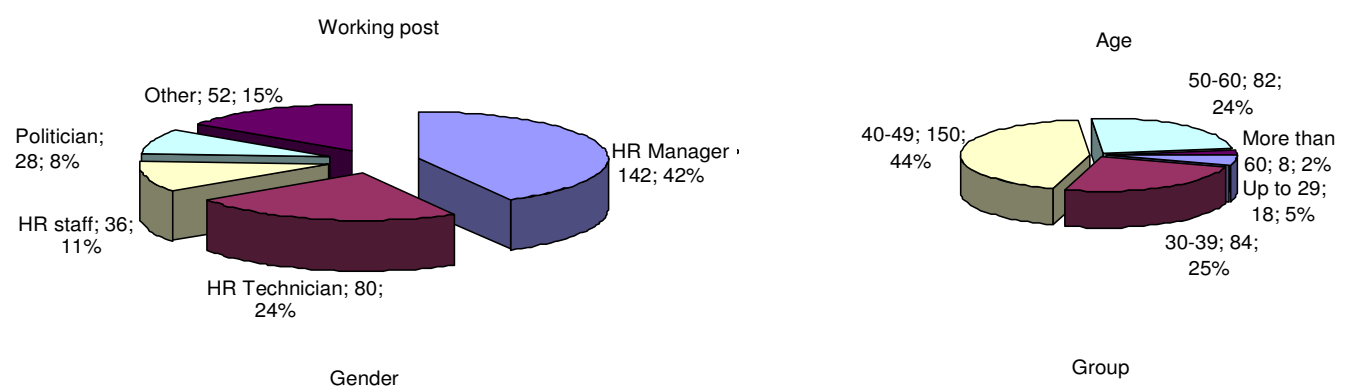

Women;
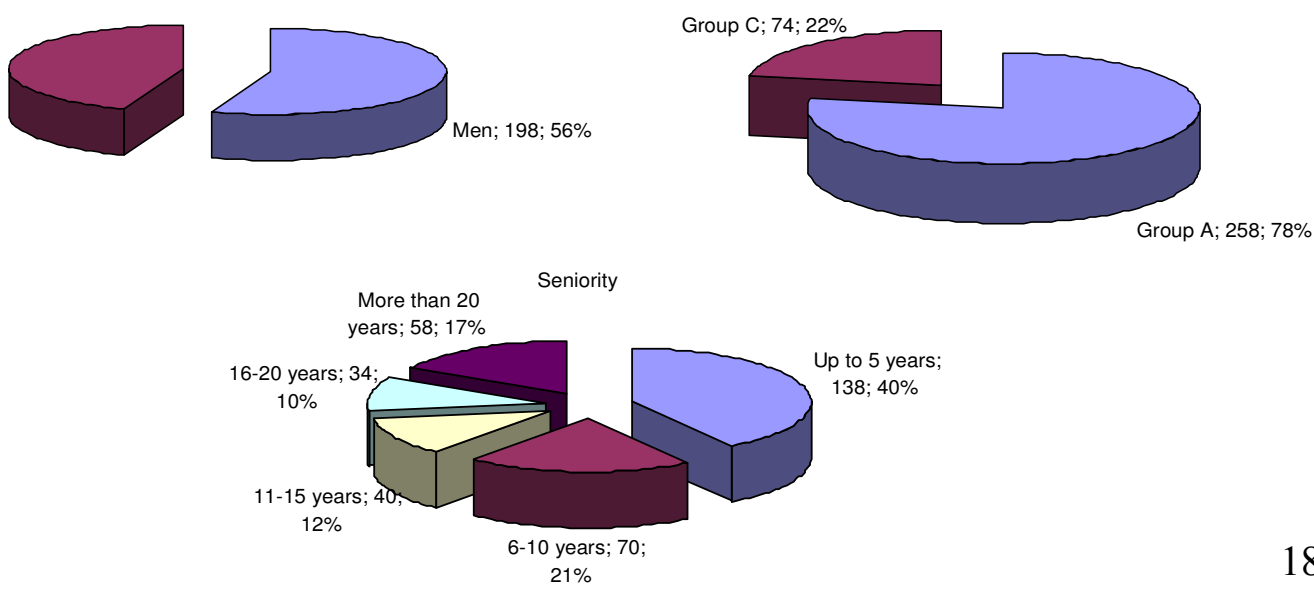
